\title{
Biodegradable polymers as floating row covers in field production of radish
}

\author{
Andrzej Kalisz ${ }^{*}$, Aneta Grabowska ${ }^{1}$, Agnieszka Sekara ${ }^{1}$, Ewa Capecka $^{1}$, Andrzej Libik ${ }^{1}$, Konrad Sulak $^{2}$, \\ and Rita Jurkow ${ }^{1}$ \\ 'University of Agriculture in Krakow, Department of Vegetable and Medicinal Plants, 29 Listopada 54, 31-425 Kraków, Poland. \\ "Corresponding author (andrzej.kalisz@urk.edu.pl). \\ ${ }^{2}$ Institute of Biopolymers and Chemical Fibers, Department of Synthetic Fibers, Sklodowskiej-Curie 19/27, 90-570 Lódz, Poland.
}

Received: 31 October 2018; Accepted: 7 February 2019; doi:10.4067/S0718-58392019000200243

\begin{abstract}
Polypropylene (PP) covers are used in radish (Raphanus sativus L. var. sativus) production to provide better microclimate for improving yield and quality, but disposing of non-degradable covers is difficult and expensive. In this work, nonwovens prepared from biodegradable polymers (aliphatic-aromatic copolyesters with and without fatty acid dimers: SB48/11, SB20/13, SB21/13, SB28/13) were tested in the field as substitutes for nonwoven PP. Minimum air temperature under biodegradable covers was higher by $0.6-0.8^{\circ} \mathrm{C}$ than under nonwoven $\mathrm{PP}$, but photosynthetically active radiation (PAR) transmission was lower by $4.1 \%$ (SB20/13) and 7.1\% (SB21/13). We observed a decrease in marketable yield of plants covered with biodegradable fleeces by 1.01 to $2.90 \mathrm{~kg} \mathrm{~m}^{-2}$ (SB48/11 and SB28/13, respectively) in spring seasons, but similar yields to nonwoven PP were obtained in the autumn seasons. Dry weight, soluble sugars, L-ascorbic acid, pigments content in radish was dependent on a specific set of environmental conditions rather than on the type of cover. However, L-ascorbic acid content in the roots increased significantly by 6.4 and $2.9 \mathrm{mg} 100 \mathrm{~g}^{-1} \mathrm{FW}$ for SB48/11 and SB20/13 (in one trial), respectively, as compared to nonwoven PP. It is possible to use biodegradable nonwovens as floating covers for radish cultivated in seasons with temperature drops.
\end{abstract}

Key words: Aliphatic-aromatic copolyesters, degradable nonwovens, PAR, Raphanus sativus, temperature, yield.

\section{INTRODUCTION}

Row covers provide a similar function to low tunnels in horticultural production, but they are used to stretch over one or more plant rows without any supportive construction. Floating row covers act to conserve heat, prevent excessive transpiration, protect from wind, heavy rain, and ground frost, and exclude pests (Hamasaki, 2013; Goldwater et al., 2018). Row covers are generally made of polypropylene (PP) or polyethylene (PE) (Olle and Bender, 2010). Petroleumderived plastics are not biodegradable and may be harmful to the environment (Vroman and Tighzert, 2009). The problem of plastic waste disposal remains serious because of the broad range of plastic used, e.g. in horticulture (Kasirajan and Ngouajio, 2012; Briassoulis et al., 2015). Biopolymers fulfil environmental concerns but they show some limitations in terms of performance, like sometimes having too short lifetime, poor thermal resistance, or mechanical properties, which are associated with higher costs. Experimental research works have focused mainly on degradable mulches and low tunnels (Martín-Closas et al., 2017), but some of the reports have shown the advantages and limitations of using biodegradable nonwoven floating films in the production of lettuce (Siwek et al., 2012), overwintering leeks (Siwek et al., 2013a), and cucumber (Zawiska and Siwek, 2014). The different effects of the use of degradable covers in vegetable production are undoubtedly due to the physical and mechanical properties of such covers, related to the production process and to the raw materials. 
Two classes of biodegradable polymer can be distinguished: synthetic and natural polymers. There are polymers produced from feedstocks derived either from petroleum resources (non-renewable resources) or from biological resources (renewable resources) (Vroman and Tighzert, 2009). Biopolymers of mineral origin include several sub-groups: aliphatic polyesters, aromatic polyesters, or blends of the two types, polyvinyl alcohols, and modified polyolefins (Chen et al., 2008; Ghanbarzadeh and Almasi, 2013).

In the present experiment, we used three degradable materials made of aliphatic-aromatic copolyesters (AAC) consisting of a mixture of aliphatic and aromatic monomers; two of these materials had the addition of the high-purity dimer acid Pripol 1009. Detailed AAC characteristics are to be found in the papers of Chen et al. (2008) and TwarowskaSchmidt et al. (2016), who presented a large range of AAC. Aliphatic-aromatic copolyesters combine good mechanical properties with biodegradability. These materials have been tested in the field production of some vegetable crops, but mainly as mulches (Kijchavengkul et al., 2008; Ngouajio et al., 2008). Some scientific reports have described effects of AAC materials used as floating row covers on vegetable crops. Siwek et al. (2012) used covers made of AAC containing a 57\%-60\% tri-component aliphatic portion (copolymers of butylene glycol and adipic, succinic, glutaric, and terephthalic acids) for covering lettuce. The yield of lettuce under this cover increased compared to that in the open field, but only in $1 \mathrm{yr}$ of the experiment. Zawiska and Siwek (2014) used AAC and polylactide (PLA) nonwovens for covering cucumber plants in the field. They observed an increase in the yield of covered plants in comparison to those in the open field, significant only in one experimental year.

Biopolymers of natural origin include agropolymers obtained by biomass fragmentation processes (polysaccharides, proteins), and biopolyesters obtained either by synthesis from bio-derived monomers (PLA) or produced by microorganisms (polyhydroxyalkanoate, PHA; polyhydroxybutyrate, PHB) (Bergeret, 2011). Harnessing plant biomass for the production of renewable polymers for agricultural purposes is an interesting direction of technology development (van Beilen and Poirier, 2008). The principal polysaccharides used in material applications are cellulose and starch; in our experiment, we used a nonwoven made of AAC mixed with starch derived from corn biomass. Although there have been some studies on biomass-based covers, they were mostly used as mulches (Waterer, 2010; Martín-Closas et al., 2017). To the best of our knowledge, there are no published works that have examined biomass-based floating covers in horticultural production. Expanding applications of agricultural biomass would not only help in reducing environmental pollution but also provide an opportunity to develop a renewable and sustainable material to be used in various advanced applications in the future (Alwani et al., 2014).

The aim of the present work was to evaluate the effects of four degradable floating row covers (SB48/11, SB20/13, SB21/13, and SB28/13) to be used as sustainable alternatives to nonwoven PP. For this purpose, three independent field experiments with radish were conducted to verify (1) that the materials met the basic assumptions of a floating film in terms of functional properties, (2) if they lead to at least similar agronomical performance as a conventional PP cover, and (3) the effectiveness of tested covers in conditions of different growing seasons.

\section{MATERIALS AND METHODS}

\section{Experimental site and plant material}

Field experiments were carried out in the experimental station at Krakow-Mydlniki (5004' N, 195' E), southern Poland, in 2012-2014, on soil classified as Fluvic Cambisol (Humic) according to the classification of the Food and Agriculture Organization of the United Nations. According to the Köppen classification, the climate of the region is humid continental (Dfb). Radish (Raphanus sativus L. var. sativus) was the investigated species, as common crop cultivated under covers, and following cultivars were used: Girox $F_{1}$ (Hild Samen), Famox $F_{1}$ (Nunhems), and Donar $F_{1}$ (Syngenta Seeds).

\section{Experimental design and field management}

Three independent experiments with radish were conducted: Experiment I (Exp. I) cover: prototype nonwoven SB48/11; sowing 12 April 2012, harvest 10 May 2012; cv. Girox $\mathrm{F}_{1}$, preliminary study, spring production; Experiment II (Exp. II) covers: two next-generation biodegradable SB20/13 and SB21/13; sowing 2 September 2013, harvest 13 October 2012; cv. Famox $\mathrm{F}_{1}$, preliminary study, autumn production; and Experiment III (Exp. III) covers: nonwoven fabric with the addition of plant biomass (SB28/13) together with SB20/13 and SB21/13; sowing 1 April 2014 and 13 August 2014, harvest 13 May 2014 and 16 October 2014; cv. Donar $\mathrm{F}_{1}$, two-seasons investigations. 
Radish seeds were sown directly in the field (Exp. I-III). The experimental design was a split-block plot, with three replicates per treatment. Rows were spaced $15 \mathrm{~cm}$ apart; the plot was one row wide and $4 \mathrm{~m}$ long (single plot area $0.6 \mathrm{~m}^{2}$ ). All cultivation practices (irrigation, plant protection, weed control, fertilization) were adapted to the production guidelines recommended for radishes. Plots were covered with nonwoven PP fleece (Agryl, $19 \mathrm{~g} \mathrm{~m}^{-2}$ ) which served as a control, and the biodegradable covers, described in details below, for the periods: 12 April-4 May 2012, 25 September-14 October 2013, 1 April-13 May 2014, and 25 September-16 October 2014.

\section{Direct covers and their properties}

The experiment involved sequential testing of floating row covers mentioned above. Degradable covers were compared against non-degradable nonwoven PP fleece (Agryl, $19 \mathrm{~g} \mathrm{~m}^{-2}$ ). The polymeric materials (AAC) and nonwovens were made by the Institute of Biopolymers and Chemical Fibres (Lódź, Poland). The spun-bonded nonwoven SB48/11 was made of AAC without modifier using a laboratory line designed by the Polmatex-Cenaro Central Research and Development Centre of Textile Machines in Lódź. The parameters of the forming process were as follows: temperature of the melt in the spinning block was $220 \pm 3{ }^{\circ} \mathrm{C}$, polymer throughput was $0.43 \pm 0.04 \mathrm{~g} \mathrm{~min}^{-1} \mathrm{hole}^{-1}$. The calender temperature was $40 \pm 1{ }^{\circ} \mathrm{C}$. SB20/13 and SB21/13 are spun-bonded nonwovens made of AAC with Pripol 1009 (a fatty acid dimer from Croda, Gouda, Netherlands), while the final nonwoven SB28/13 was made of AAC with the addition of a modifier made from plant biomass (corn starch). Detailed characteristics of nonwovens are presented in Table 1. Always new nonwovens (both biodegradable and non-degradable) were stretched over the plants in each season. The rate of degradation of the tested materials will be presented elsewhere.

\section{Scanning electron microscopy (SEM)}

SEM images (courtesy K. Sulak) were taken with the use of a Quanta 200 scanning electron microscope (FEI Co., Hillsboro, Oregon, USA). The examination was accomplished in a low vacuum in natural conditions without spraying. Example photos presented in Figure 1 shows the fibre surface of different polymer materials obtained during the present research project: without any modifier (material similar to SB48/11), with the commercial modifier Pripol 1009 (as in SB20/13 and SB21/13), or with modifier produced from plant biomass (SB28/13). The purpose of doping fatty acid dimers was to utilize products derived from biomass.

\section{Plant measurements and radish yield}

Radishes were harvested at the stage of root maturity. On a randomly selected 45 plants per treatment (15 per replicate), all fully developed leaves were counted, then cut and photographed to determine their area and perimeter with the use of a WinDIAS Image Analysis System (Delta-T Devices, Cambridge, UK). The horizontal and vertical diameter of the radish roots was measured using an electronic calliper. Root shape was calculated as the length to diameter ratio. Pithiness was determined visually on 45 roots ( 15 per replicate) using the scale: 0 no symptoms, 1 trace symptoms,

Table 1. Physical and mechanical properties of degradable nonwovens tested in the experiments.

\begin{tabular}{lrrrr}
\hline Properties & SB48/11 & SB20/13 & SB21/13 & SB28/13 \\
\hline Thickness, mm & 0.26 & 0.40 & 0.38 & 0.41 \\
Mass per unit area, g m ${ }^{-2}$ & 71.30 & 74.20 & 75.20 & 81.80 \\
Fibre diameter, $\mu \mathrm{m}$ & 15.30 & 24.20 & 23.90 & 24.50 \\
Breaking force MD, N & 11.00 & 5.35 & 4.29 & 4.46 \\
Breaking force TD, N & 8.86 & 6.01 & 4.88 & 3.54 \\
Elongation at break MD, \% & 108.00 & 68.80 & 59.00 & 60.10 \\
Elongation at break TD, \% & 132.00 & 123.00 & 101.00 & 88.60 \\
Tenacity strength MD, MPa & 0.85 & 0.27 & 0.23 & 0.22 \\
Tenacity strength TD, MPa & 0.68 & 0.30 & 0.24 & 0.17 \\
Tearing strength MD, N & 12.60 & 7.80 & 7.20 & 4.70 \\
Tearing strength TD, N & 10.60 & 5.40 & 5.40 & 4.90 \\
\hline
\end{tabular}

MD: Machine direction, TD: transverse direction. 
Figure 1. Example of scanning electron microscopy (SEM) photos of the surface of nonwoven fibres: Without modifier (A), with commercial modifier Pripol 1009 (B), biomass-based fibrous material (C).

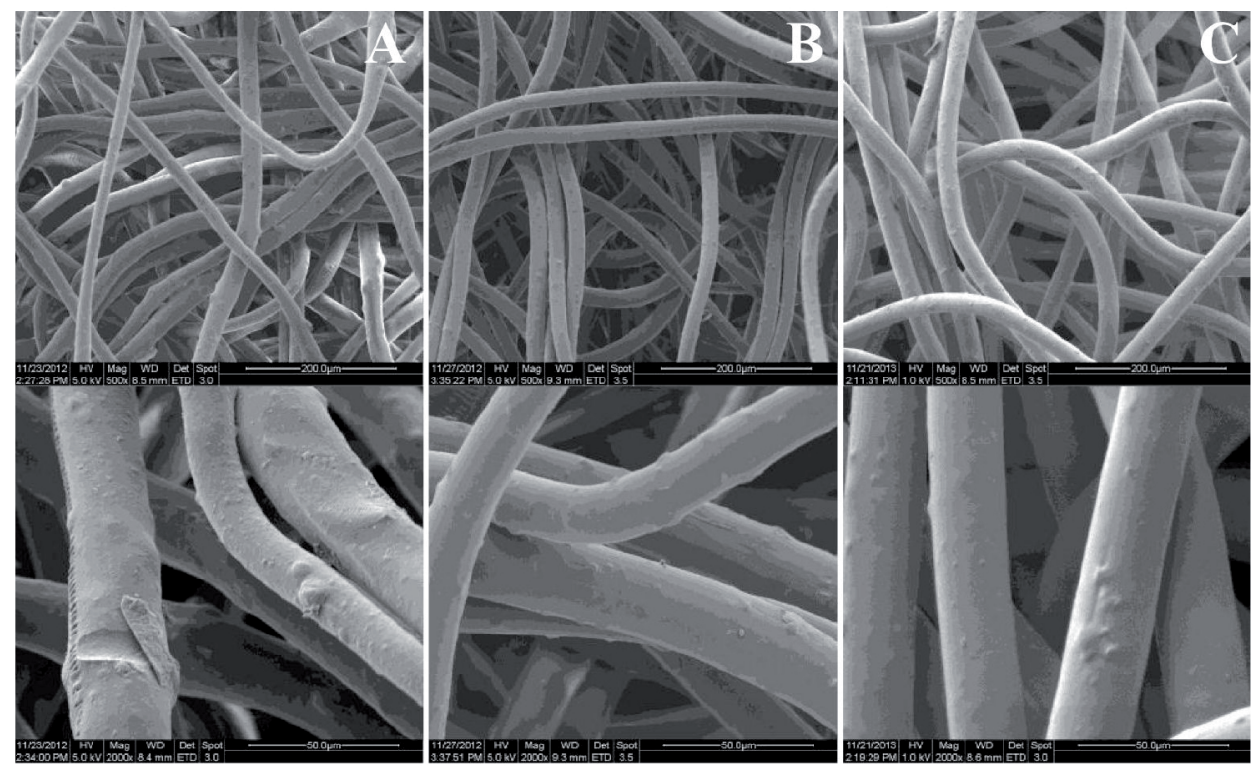

2 weak pithiness, 3 strong pithiness; values for a particular replicate were averaged. The parameters determining yield included: number and weight of roots per $1 \mathrm{~m}^{2}$, number of marketable roots of small and shapeless roots and of cracked roots, average weight of a marketable root, and quality structure of the radish yield. Weight of leaves per $1 \mathrm{~m}^{2}$ and leaf/ root weight ratio were also determined.

\section{Air temperature}

In experiment III, the temperature of the air under covers was monitored by HOBO U12 data loggers (Onset Computer Corporation, Bourne, Massachusetts, USA). The sensors were placed directly onto the plots and shielded in order to avoid direct sunlight. The temperature was recorded hourly, downloaded via HOBOware Pro 3.7.11 software (Onset Comp. Corp.), and presented as daily averages of 24 values for mean, maximum, and minimum temperature. Data for the spring season (2 April-12 May 2014) are presented. The warmest and coldest days were chosen for presenting a comparison of the course of temperature (hourly intervals) under different covers on 22 and 16 April, respectively.

\section{Photosynthetically active radiation (PAR)}

In experiment II, PAR was measured via PAR sensors (S-LIA-M003, Onset Comp. Corp.) during summer 2013 (1-31 August, measurement range of 0 to $2500 \mu \mathrm{mol} \mathrm{m}^{-2} \mathrm{~s}^{-1}$ over a wavelength range of $400-700 \mathrm{~nm}$ ). Sensors were connected to a HOBO Weather Station (Onset Comp. Corp.) and placed under particular covers stretched over additional experimental plots. The PAR sensors worked in the measurement-averaging mode (logging interval: $1 \mathrm{~h}$, but the sampling interval was set to $10 \mathrm{~min}$; each data point within $1 \mathrm{~h}$ was the average of six measurements). PAR data were presented as averages for days as well as for the sunniest (5 August) and most cloudy days (10 August) of the summer season at hourly intervals; values below $3 \mu \mathrm{mol} \mathrm{m} \mathrm{m}^{-2} \mathrm{~s}^{-1}$ were omitted. Average external PAR for August was $633.1 \mu \mathrm{mol} \mathrm{m} \mathrm{m}^{-2} \mathrm{~s}^{-1}$.

\section{Laboratory assays}

Fresh roots were weighed and oven-dried at $65^{\circ} \mathrm{C}$ and then re-weighed to determine dry weight using a balance (A120S, Sartorius AG, Goettingen, Germany). Soluble sugars were determined by the anthrone method (Yemm and Willis, 1954). Plant material was mixed with $80 \%$ ethanol. Following addition of anthrone, the samples were placed in a water bath for 30 $\min \left(100{ }^{\circ} \mathrm{C}\right)$, cooled down to $20-22^{\circ} \mathrm{C}$, then soluble sugars were determined at $625 \mathrm{~nm}$ (Helios Beta spectrophotometer, Thermo Fisher Scientific Inc., Waltham, Massachusetts, USA). The L-ascorbic acid content was determined by Tillman's titration method (Krelowska-Kulas, 1993). Homogenized plant material $\left(50 \mathrm{~g}\right.$ ) was mixed with $200 \mathrm{~cm}^{3}$ acetic acid (acidity 
regulator), and after $30 \mathrm{~min}$, the extract was titrated with Tillman's reagent (2,6-dichlorophenolindophenol). Dry weight, soluble sugars, chlorophyll $a$ and $b$, and carotenoids were determined additionally in the radish leaves in 2012 (Exp. I) to compare the effect of degradable nonwoven material on the accumulation of some chemical components in underground and above-ground plant parts. To assess chlorophyll $a$, chlorophyll $b$, and carotenoid content, samples $(0.1 \mathrm{~g})$ were ground with $3 \mathrm{mg}$ magnesium carbonate $\left(\mathrm{MgCO}_{3}\right)$; chlorophylls ( $\mathrm{Chl} a$ and $\mathrm{Chl} b$ ) and carotenoids (Car) were extracted in $80 \%$ $(\mathrm{v} / \mathrm{v})$ aqueous acetone $\left(25 \mathrm{~cm}^{3}\right)$. After $0.5 \mathrm{~h}$ in the dark, absorbance of the extracts was read at 663,646 , and $470 \mathrm{~nm}$ on a Helios Beta spectrophotometer (Thermo Fisher Scientific Inc., Waltham, USA). The chlorophyll and carotenoid content was calculated using the equations described by Lichtenthaler and Wellburn (1983).

\section{Statistical analysis}

One-way ANOVA was used to test differences between nonwoven materials. Homogenous groups were identified by t-test (2012; Exp. I) or Tukey's HSD post hoc test (2013-2014; Exp. II and III) comparison at p $\leq 0.05$. The effects of nonwoven type were evaluated at three levels of significance: $p \leq 0.05, p \leq 0.01$, and $p \leq 0.001$. All statistical analyses were performed using Statistica 13.1 (Dell Inc., Round Rock, Texas, USA).

\section{RESULTS AND DISCUSSION}

\section{Air temperature under different types of cover}

The different floating row covers had slightly different effects on air temperature (Figure 2). Minimum air temperature under Control PP was around $6.8^{\circ} \mathrm{C}$ (on average); under biodegradable covers, this temperature was higher by about 0.6$0.8^{\circ} \mathrm{C}$. Mean temperature was nonsignificantly different between covers, and it was within the range of $13.4^{\circ} \mathrm{C}(\mathrm{SB} 20 / 13)$ to $14.0^{\circ} \mathrm{C}$ (SB28/13). The maximum temperature turned out to be more varied. Average maximum temperature was lowest under SB20/13 nonwoven $\left(23{ }^{\circ} \mathrm{C}\right.$, on average), reaching a level of $24.3{ }^{\circ} \mathrm{C}$ under Control PP and SB28/13 nonwovens. Thus, SB20/13 provided somewhat milder maximum temperatures than other covers, while SB28/13 protected better against minimum temperatures.

The positive impact of non-degradable nonwovens on air temperature was described by Rekika et al. (2008), Olle and Bender (2010), Kalisz et al. (2014), and Goldwater et al. (2018); however, the effects of degradable nonwovens have not been widely investigated in this respect. Most papers have focused on soil temperature and degradable mulches (Ngouajio

Figure 2. Air temperature under different nonwovens, spring 2014.

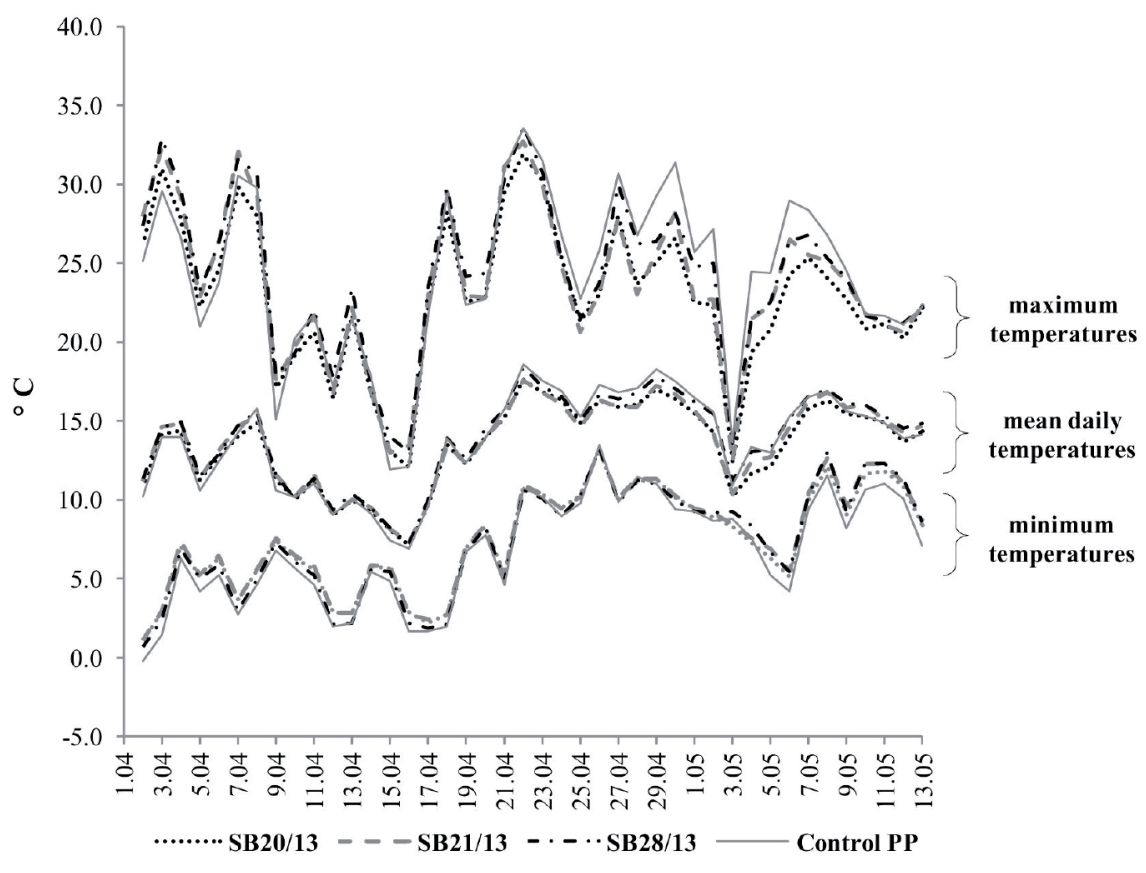

PP: Polypropylene. 
et al., 2008), or soil temperature and degradable floating row covers (Siwek et al., 2012; 2013a). These authors stated that the influence of nonwovens on soil temperature is strictly connected with the material used. In the present study, we showed that transfer of heat through the fibrous materials tested was slightly different, affecting also the air temperature under covers, and depended mainly on the thickness, density, and chemical components of the nonwoven; differences were especially visible in the case of extreme temperatures.

Analyzing the recorded temperature data, we chose the days with the highest and lowest average temperature to evaluate the course of daily air temperature under different covers (Figure 3). A similar level of temperature under Control PP and SB28/13 was observed during the warmest day. The daily average for these nonwovens on that day was 18.6 and $18.4^{\circ} \mathrm{C}$, respectively. The temperature under SB21/13 and SB20/13 covers was lower, especially in the morning hours, than under Control PP. During the coldest day, biodegradable covers provided higher temperatures, mainly up to noon, than the commercial PP nonwoven. At noon, a higher temperature was observed under both SB28/13 and SB21/13 covers (by about 0.9 to $1.5^{\circ} \mathrm{C}$ ) in comparison to that under SB20/13 and the PP nonwoven. The average temperature during the coldest day under biodegradable covers, including SB20/13, was higher by $0.2-0.4^{\circ} \mathrm{C}$ in comparison to that under the PP nonwoven. The results show that the materials tested have different thermal conductivity, which is dependent on the type of nonwoven fabric and the time of day.

\section{PAR under different types of covers}

During the measurement period, PAR under the commercial PP nonwoven was usually higher than under biodegradable covers (Figure 4). Daily average PAR under the PP nonwoven in August ranged from 112.3 to $654.1 \mu \mathrm{mol} \mathrm{m}^{-2} \mathrm{~s}^{-1}$; on average it was $450.8 \mu \mathrm{mol} \mathrm{m}^{-2} \mathrm{~s}^{-1}$. These values for SB20/13 and SB21/13 were 108.6 to $635.3 \mu \mathrm{mol} \mathrm{m}^{-2} \mathrm{~s}^{-1}$ (on average $432.1 \mu \mathrm{mol} \mathrm{m} \mathrm{m}^{-1} \mathrm{~s}^{-1}$ ) and 93.8 to $605.5 \mu \mathrm{mol} \mathrm{m} \mathrm{m}^{-2} \mathrm{~s}^{-1}$ (on average $418.6 \mu \mathrm{mol} \mathrm{m}^{-2} \mathrm{~s}^{-1}$ ), respectively. In comparison to external PAR, the decrease was $28.8 \%$ (Control PP), 31.7\% (SB20/13), and 33.9\% (SB21/13). Radiation transmission through covers varied from $65 \%$ to $85 \%$, depending on dust accumulation on the cover and water vapor condensation on the inner surface of the fabric, but transmission depended also on the type of nonwoven (Kalisz et al., 2018). Siwek et al. (2012) recorded transmittance of PAR for an AAC degradable nonwoven of $59.7 \%$ of external radiation, while transmittance for a polylactide degradable nonwoven was higher by around $8 \%$.

The daily course of PAR under the covers tested during the sunniest and cloudiest days was different (Figure 5). During the sunniest day, better transmittance of PAR up to noon through degradable nonwovens was noteworthy. PAR was higher under the commercial PP nonwoven between 13:00 and 18:00 h by $3.9 \%$ to $46.5 \%$ compared to that under biodegradable nonwovens. Slightly higher PAR transmittance (by around 4\%) was observed for SB20/13 in comparison to SB21/13 on that day. On the cloudiest day, PAR level under Control PP and SB20/13 was quite similar, while transmittance of

Figure 3. Daily course of temperature during the warmest (A) and coldest (B) days, spring 2014.

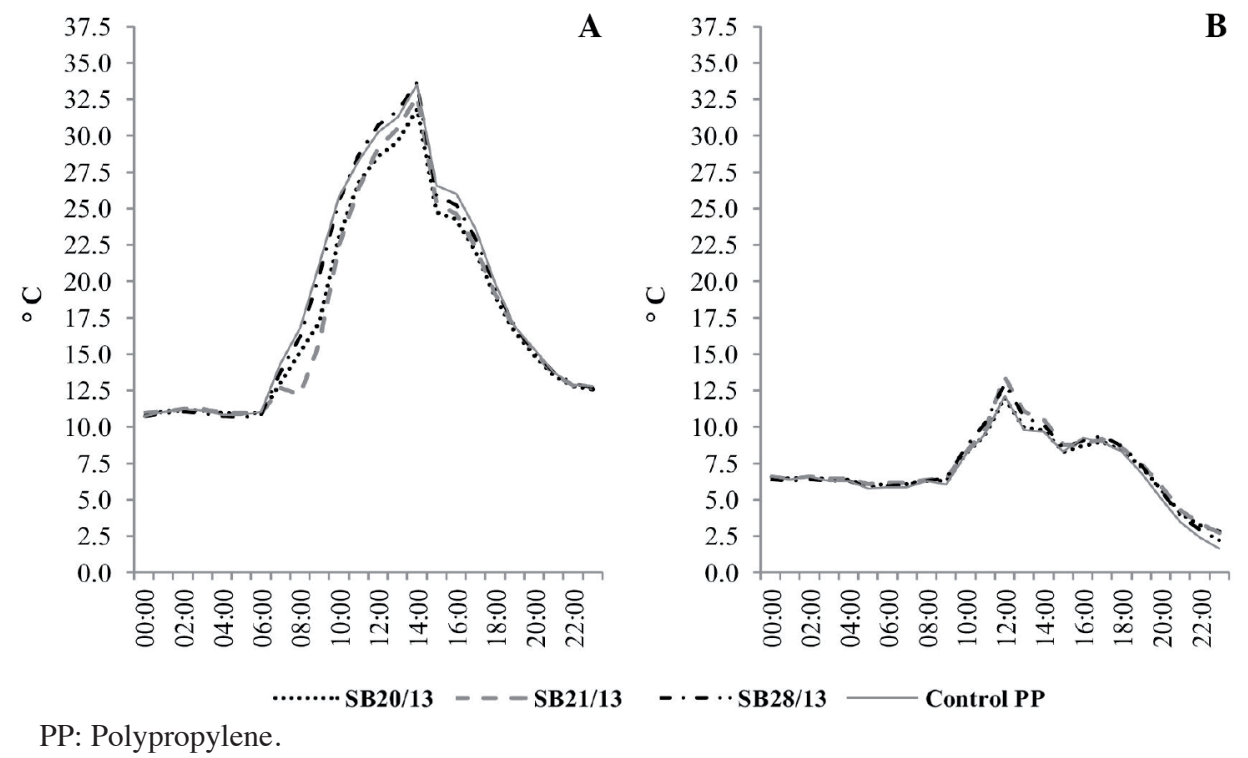


Figure 4. Photosynthetically active radiation (PAR) under different nonwovens, summer 2013.

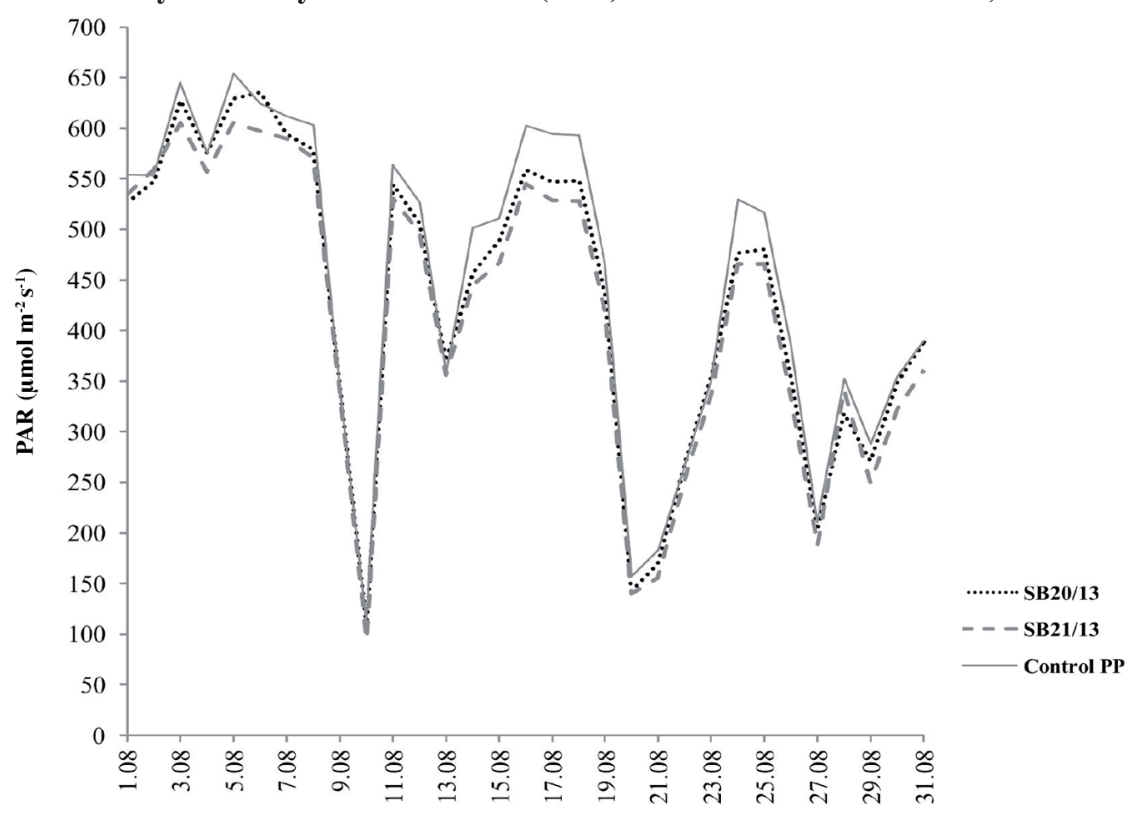

PP: Polypropylene.

Figure 5. Daily course of photosynthetically active radiation (PAR) during the sunniest (A) and cloudiest (B) days, summer 2013.
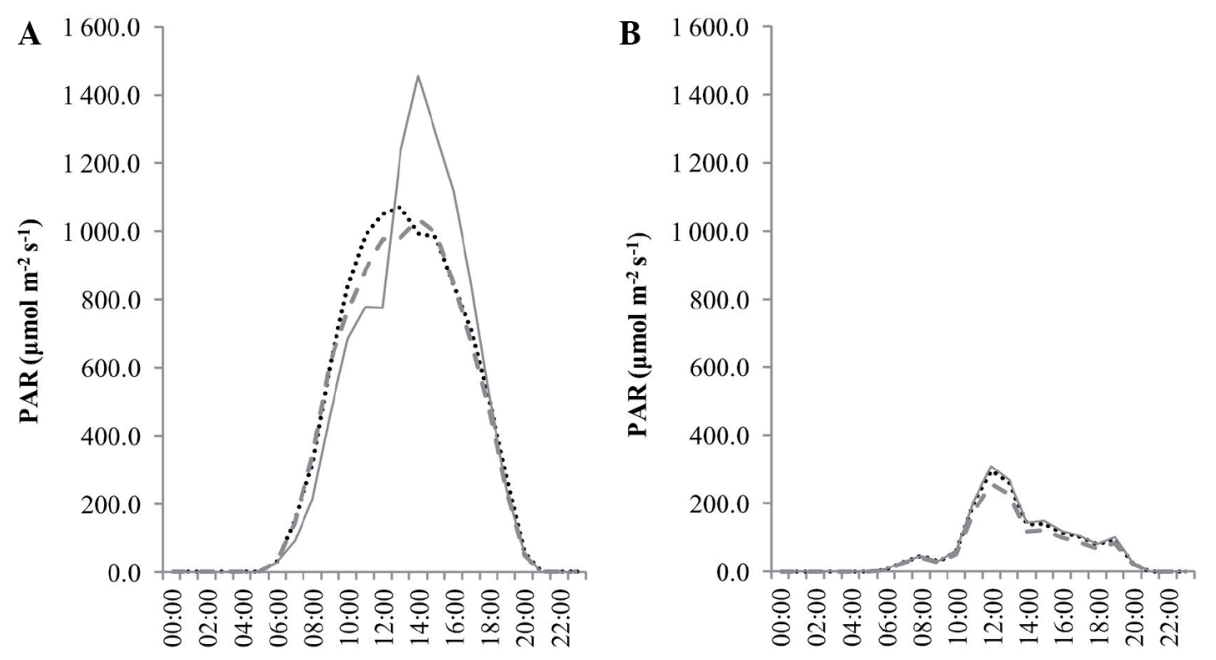

PP: Polypropylene.

SB21/13 was lower by $16.5 \%$ and $13.6 \%$ in comparison to Control PP and SB20/13, respectively. This was an interesting observation; we observed that air temperatures during forenoon and early afternoon hours affected water condensation on nonwovens. We noted strong water impregnation of the biodegradable materials tested; sometimes, even a high external temperature did not completely dry the covers, which could have reduced the light transmission in comparison to the faster-drying PP cover.

\section{Radish morphology and root internal quality}

In the trial conducted in 2012 (Exp. I), the prototype cover SB48/11 did not affect leaf number, leaf area, or perimeter; however, root diameter and root length increased (Table 2). Root pithiness occurred less frequently than in the case of radishes covered with the PP nonwoven. Plants covered with degradable polymers usually developed fewer leaves (Tables 3 and 4); this was confirmed statistically for SB21/13 in autumn 2013 (Exp. II) and for SB20/13 in spring 2014 (Exp. III). 
Table 2. Morphological parameters of radishes as affected by nonwoven type in experiment I. Spring 2012.

\begin{tabular}{|c|c|c|c|c|c|c|c|}
\hline Nonwoven type & $\begin{array}{c}\text { Leaf } \\
\text { number }\end{array}$ & Leaf area & $\begin{array}{c}\text { Leaf } \\
\text { perimeter }\end{array}$ & $\begin{array}{c}\text { Root } \\
\text { diameter }\end{array}$ & $\begin{array}{l}\text { Root } \\
\text { length }\end{array}$ & $\begin{array}{l}\text { Root shape } \\
\text { factor }\end{array}$ & $\begin{array}{c}\text { Root } \\
\text { pithiness }\end{array}$ \\
\hline & & $\mathrm{cm}^{2}$ & & $\mathrm{~cm}$ & - & & \\
\hline SB48/11 & $5.4 \mathrm{a}$ & $26.78 \mathrm{a}$ & $40.82 \mathrm{a}$ & $2.38 \mathrm{a}$ & $2.78 \mathrm{a}$ & $1.167 \mathrm{a}$ & $0.311 \mathrm{a}$ \\
\hline Control PP & $5.3 \mathrm{a}$ & $24.99 \mathrm{a}$ & $37.98 \mathrm{a}$ & $2.68 b$ & $3.26 \mathrm{~b}$ & $1.214 \mathrm{a}$ & $0.867 \mathrm{~b}$ \\
\hline Significance & ns & ns & ns & $* *$ & $*$ & ns & $* *$ \\
\hline
\end{tabular}

Means within a column are significantly different according to t-test $(\mathrm{p} \leq 0.05)$.

$*, * *$ Significant at the 0.05 and 0.01 probability levels, respectively.

ns: Nonsignificant; PP: polypropylene. Characteristics of nonwovens: see Materials and Methods.

Table 3. Morphological parameters of radishes as affected by nonwoven type in experiment II. Autumn 2013.

\begin{tabular}{|c|c|c|c|c|c|c|c|}
\hline Nonwoven type & $\begin{array}{c}\text { Leaf } \\
\text { number }\end{array}$ & Leaf area & $\begin{array}{c}\text { Leaf } \\
\text { perimeter }\end{array}$ & $\begin{array}{c}\text { Root } \\
\text { diameter }\end{array}$ & $\begin{array}{l}\text { Root } \\
\text { length }\end{array}$ & $\begin{array}{l}\text { Root shape } \\
\text { factor }\end{array}$ & $\begin{array}{c}\text { Root } \\
\text { pithiness }\end{array}$ \\
\hline & & $\mathrm{cm}^{2}$ & 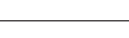 & $\mathrm{cm}$ & - & & \\
\hline SB20/13 & $6.2 b$ & $45.72 \mathrm{a}$ & $51.58 \mathrm{a}$ & $31.34 \mathrm{a}$ & $32.40 \mathrm{a}$ & $1.034 \mathrm{a}$ & $0.844 \mathrm{a}$ \\
\hline $\mathrm{SB} 21 / 13$ & $5.5 \mathrm{a}$ & $45.82 \mathrm{a}$ & $51.13 \mathrm{a}$ & $31.12 \mathrm{a}$ & $32.63 \mathrm{ab}$ & $1.048 \mathrm{a}$ & $0.400 \mathrm{a}$ \\
\hline Control PP & $6.4 \mathrm{~b}$ & $49.10 \mathrm{a}$ & $53.89 \mathrm{a}$ & $32.07 \mathrm{a}$ & $35.13 b$ & $1.095 b$ & $0.600 \mathrm{a}$ \\
\hline Significance & $* *$ & ns & ns & ns & $*$ & $*$ & ns \\
\hline
\end{tabular}

Means within a column are significantly different according to Tukey's HSD test $(\mathrm{p} \leq 0.05)$.

$*, * *$ Significant at the 0.05 and 0.01 probability levels, respectively.

ns: Nonsignificant; PP: polypropylene. Characteristics of nonwovens: see Materials and Methods.

Table 4. Morphological parameters of radishes as affected by nonwoven type in experiment III.

\begin{tabular}{|c|c|c|c|c|c|c|c|}
\hline Nonwoven type & $\begin{array}{c}\text { Leaf } \\
\text { number }\end{array}$ & Leaf area & $\begin{array}{c}\text { Leaf } \\
\text { perimeter }\end{array}$ & $\begin{array}{c}\text { Root } \\
\text { diameter }\end{array}$ & $\begin{array}{l}\text { Root } \\
\text { length }\end{array}$ & $\begin{array}{l}\text { Root shape } \\
\text { factor }\end{array}$ & $\begin{array}{c}\text { Root } \\
\text { pithiness }\end{array}$ \\
\hline & & $\mathrm{cm}^{2}$ & & $\mathrm{~cm}$ & - & & \\
\hline \multicolumn{8}{|l|}{ Spring 2014} \\
\hline SB20/13 & $5.7 \mathrm{a}$ & $45.55 \mathrm{a}$ & $60.87 \mathrm{ab}$ & $29.68 \mathrm{a}$ & $32.86 \mathrm{ab}$ & $1.107 \mathrm{a}$ & $1.133 \mathrm{a}$ \\
\hline SB21/13 & $6.0 \mathrm{ab}$ & $49.78 \mathrm{ab}$ & $57.31 \mathrm{a}$ & $30.57 \mathrm{ab}$ & $35.68 b c$ & $1.167 \mathrm{a}$ & $1.244 \mathrm{a}$ \\
\hline SB28/13 & $5.9 \mathrm{ab}$ & $54.72 b c$ & $66.37 b c$ & $29.61 \mathrm{a}$ & $32.06 \mathrm{a}$ & $1.083 \mathrm{a}$ & $1.178 \mathrm{a}$ \\
\hline Control PP & $6.6 b$ & $59.83 c$ & $70.01 \mathrm{c}$ & $32.14 b$ & $36.27 \mathrm{c}$ & $1.129 \mathrm{a}$ & $1.178 \mathrm{a}$ \\
\hline Significance & $*$ & $* *$ & $* *$ & $*$ & $* *$ & ns & ns \\
\hline \multicolumn{8}{|l|}{ Autumn 2014} \\
\hline SB20/13 & $5.5 \mathrm{a}$ & $34.29 \mathrm{~b}$ & $59.76 b$ & $26.81 \mathrm{ab}$ & $36.56 \mathrm{~b}$ & $1.364 b$ & $0.156 a$ \\
\hline SB21/13 & $5.6 \mathrm{a}$ & $27.05 \mathrm{a}$ & $49.32 \mathrm{a}$ & $29.61 b$ & $32.42 \mathrm{ab}$ & $1.096 \mathrm{a}$ & $0.244 \mathrm{a}$ \\
\hline SB28/13 & $5.5 \mathrm{a}$ & $32.93 b$ & $51.29 \mathrm{a}$ & $26.99 \mathrm{ab}$ & $33.21 \mathrm{ab}$ & $1.232 \mathrm{ab}$ & $0.044 \mathrm{a}$ \\
\hline Control PP & $5.7 \mathrm{a}$ & $33.95 b$ & $58.35 b$ & $26.12 \mathrm{a}$ & $31.63 \mathrm{a}$ & $1.210 \mathrm{a}$ & $0.089 \mathrm{a}$ \\
\hline Significance & ns & $*$ & ** & $*$ & $*$ & $* *$ & ns \\
\hline
\end{tabular}

Means within a column are significantly different according to Tukey's HSD test ( $\mathrm{p} \leq 0.05)$.

$*, * *$ Significant at the 0.05 and 0.01 probability levels, respectively.

ns: Nonsignificant; PP: polypropylene. Characteristics of nonwovens: see Materials and Methods.

Leaf area and leaf perimeter were affected by nonwoven type in both seasons of 2014 (Exp. III). The area of the leaves of plants under SB20/13 and SB21/13 in the spring was lower than in the control plants; this was confirmed also for SB21/13 in the autumn. A similar observation was made for leaf perimeter in the spring; however, in the autumn, leaves of plants covered with SB21/13 and SB28/13 had a smaller perimeter than control ones. In spring 2014, plants covered with SB28/13 had significantly smaller root diameter and root length in comparison to the Control PP nonwoven. In autumn 2014, control plants tended to form roots of smaller diameter and length, especially in comparison to SB21/13 (root diameter) or SB20/13 (root length). In the years 2013-2014 there was no effect of biodegradable covers on the pithiness of radish roots.

It is known that covering with a nonwoven fabric improves plant growth in comparison to open-field plants (Olle and Bender, 2010) through modification of air and soil temperature, humidity, and $\mathrm{CO}_{2}$ concentration; however, the effects of floating row covers may depend on the type of polymer applied. Kalisz et al. (2017) found similar values for biometrical 
parameters of leek plants covered with PP and polylactide (PLA) nonwovens. Siwek et al. (2013b) observed some effects of tested degradable covers (AAC and PLA of various mass per unit area) on onion morphology in comparison to a standard PP nonwoven, e.g. Bionolle $100 \mathrm{~g} \mathrm{~m}^{-2}$ and AAC $50 \mathrm{~g} \mathrm{~m}^{-2}$ increased bulb diameter; moreover, some modifications of plant height and leaf length also occurred, but they were year-dependent. In a complex system of environmental factors acting on plants, the differences between the effects of direct covers on plant growth may be less visible. Polymeric materials have different physical properties and can change microclimate conditions in the plant surroundings in various ways (Hamasaki, 2013; Sideman, 2017; Ozturk et al., 2018), which can affect plant growth and morphology. We suppose that in the current experiment differences in the morphological parameters of plants resulted more from differences in PAR intensity than from differences in air temperature under specific cover.

\section{Radish yield}

Prototype SB48/11 polymer used as a direct cover decreased the marketable yield $\left(\mathrm{kg} \mathrm{m}^{-2}\right)$ of radish roots (Table 5; Exp. I). Mean root weight of plants covered with this degradable cover was also lower, and was associated with a higher leaf:root weight ratio, since plants under SB48/11 and nonwoven PP had similar leaf weight. Nonsignificant changes in yield parameters were observed in 2013 (Exp. II) or in autumn 2014 (Exp. III) between direct covers (Tables 6 and 7). Yield $\left(\mathrm{kg} \mathrm{m}^{-2}\right)$ of radishes from Exp. III covered with biodegradable materials in spring 2014 was lower than that of control plants. Mean root weight was also lower in that case. The number of radish roots collected from plots covered with SB20/13 was significantly higher than from plots covered with SB21/13 and SB28/13. Higher leaf:root weight ratio of plants under SB28/13 in comparison to Control PP was observed in spring 2014.

Nonwoven fleece is known to increase the yield of vegetable crops in comparison to the open field (Olle and Bender, 2010). This is due to the management of ambient temperature and humidity, as well as $\mathrm{CO}_{2}$ concentration under covers, which allows for significant improvements in the yield. In the present study, comparison of different direct covers showed a less favorable effect of biodegradable materials on the yield parameters tested, especially in 2012 and in spring 2014. In autumn seasons (2013 and 2014), the yield of radishes covered with degradable biopolymers was comparable to that under nonwoven PP, which is quite a good forecast. Siwek et al. (2012) observed similar yields for lettuce covered with degradable nonwovens made of Bionolle $\left(100 \mathrm{~g} \mathrm{~m}^{-2}\right)$ and AAC $\left(75 \mathrm{~g} \mathrm{~m}^{-2}\right)$ in comparison to nonwoven PP. Siwek et al. (2013b) noted a lower yield for onions under AAC covers $\left(50 \mathrm{~g} \mathrm{~m}^{-2}\right)$ when compared to a non-degradable nonwoven, but yields of onions covered with other biodegradable polymers (AAC $75 \mathrm{~g} \mathrm{~m}^{-2}$; Bionolle $59 \mathrm{~g} \mathrm{~m}^{-2}$; Bionolle $100 \mathrm{~g} \mathrm{~m}^{-2}$ ) were

Table 5. Yield parameters of radishes as well as mean leaf weight and leaf:root weight ratio as affected by nonwoven type in experiment I. Spring 2012.

\begin{tabular}{lccccc}
\hline Nonwoven type & \multicolumn{2}{c}{ Marketable yield } & $\begin{array}{c}\text { Mean root } \\
\text { weight }\end{array}$ & $\begin{array}{c}\text { Mean leaf } \\
\text { weight }\end{array}$ & $\begin{array}{c}\text { Leaf:root } \\
\text { weight ratio }\end{array}$ \\
\hline SB48/11 & $\mathrm{kg} \mathrm{m}^{-2}$ & roots m & $\mathrm{g}$ & $\mathrm{kg} \mathrm{m}^{-2}$ & \\
Control PP & $1.25 \mathrm{a}$ & $160.0 \mathrm{a}$ & $7.81 \mathrm{a}$ & $0.76 \mathrm{a}$ & $0.517 \mathrm{~b}$ \\
Significance & $2.26 \mathrm{~b}$ & $192.2 \mathrm{a}$ & $11.76 \mathrm{~b}$ & $0.83 \mathrm{a}$ & $0.283 \mathrm{a}$ \\
& $*$ & $\mathrm{~ns}$ & $* * *$ & $\mathrm{~ns}$ & $* * *$
\end{tabular}

Means within a column are significantly different according to t-test $(\mathrm{p} \leq 0.05)$.

$*$,***Significant at the 0.05 and 0.001 probability levels, respectively.

ns: Nonsignificant; PP: polypropylene. Characteristics of nonwovens: see Materials and Methods.

Table 6. Yield parameters of radishes as well as mean leaf weight and leaf:root weight ratio as affected by nonwoven type in experiment II. Autumn 2013.

\begin{tabular}{lccccc}
\hline Nonwoven type & \multicolumn{2}{c}{ Marketable yield } & $\begin{array}{c}\text { Mean root } \\
\text { weight }\end{array}$ & $\begin{array}{c}\text { Mean leaf } \\
\text { weight }\end{array}$ & $\begin{array}{c}\text { Leaf:root } \\
\text { weight ratio }\end{array}$ \\
\hline SB20/13 & $\mathrm{kg} \mathrm{m}^{-2}$ & roots m & $\mathrm{g}$ & $\mathrm{kg} \mathrm{m}^{-2}$ & \\
$\mathrm{SB} 21 / 13$ & $1.72 \mathrm{a}$ & $85.33 \mathrm{a}$ & $20.16 \mathrm{a}$ & $1.17 \mathrm{a}$ & $0.559 \mathrm{a}$ \\
Control PP & $1.64 \mathrm{a}$ & $89.78 \mathrm{a}$ & $18.27 \mathrm{a}$ & $0.99 \mathrm{a}$ & $0.473 \mathrm{a}$ \\
Significance & $2.27 \mathrm{a}$ & $118.22 \mathrm{a}$ & $19.20 \mathrm{a}$ & $1.29 \mathrm{a}$ & $0.491 \mathrm{a}$ \\
\hline
\end{tabular}

Means within a column are significantly different according to Tukey's HSD test ( $\mathrm{p} \leq 0.05)$.

*, ***Significant at the 0.05 and 0.001 probability levels, respectively.

ns: Nonsignificant; PP: polypropylene. Characteristics of nonwovens: see Materials and Methods. 
Table 7. Yield parameters of radishes as well as mean leaf weight and leaf:root weight ratio as affected by nonwoven type in experiment III.

\begin{tabular}{lccccc}
\hline Nonwoven type & \multicolumn{2}{c}{ Marketable yield } & $\begin{array}{c}\text { Mean root } \\
\text { weight }\end{array}$ & $\begin{array}{c}\text { Mean leaf } \\
\text { weight }\end{array}$ & $\begin{array}{c}\text { Leaf:root } \\
\text { weight ratio }\end{array}$ \\
\hline Spring 2014 & $\mathrm{kg} \mathrm{m}^{-2}$ & roots m ${ }^{-2}$ & $\mathrm{~g}$ & $\mathrm{~kg} \mathrm{~m}^{-2}$ & \\
SB20/13 & & & & & \\
SB21/13 & $3.82 \mathrm{a}$ & $158.9 \mathrm{~b}$ & $24.04 \mathrm{a}$ & $2.19 \mathrm{a}$ & $0.488 \mathrm{ab}$ \\
SB28/13 & $2.94 \mathrm{a}$ & $118.9 \mathrm{a}$ & $24.73 \mathrm{a}$ & $1.93 \mathrm{a}$ & $0.536 \mathrm{ab}$ \\
Control PP & $2.46 \mathrm{a}$ & $120.6 \mathrm{a}$ & $20.40 \mathrm{a}$ & $1.76 \mathrm{a}$ & $0.633 \mathrm{~b}$ \\
Significance & $5.36 \mathrm{~b}$ & $144.4 \mathrm{ab}$ & $37.12 \mathrm{~b}$ & $2.15 \mathrm{a}$ & $0.373 \mathrm{a}$ \\
Autumn 2014 & $* * *$ & $*$ & $* *$ & $\mathrm{~ns}$ & $*$ \\
SB20/13 & & & & & \\
SB21/13 & $1.61 \mathrm{a}$ & $133.3 \mathrm{a}$ & $12.08 \mathrm{a}$ & $2.42 \mathrm{a}$ & $0.833 \mathrm{a}$ \\
SB28/13 & $2.43 \mathrm{a}$ & $181.1 \mathrm{a}$ & $13.42 \mathrm{a}$ & $2.89 \mathrm{a}$ & $0.850 \mathrm{a}$ \\
Control PP & $2.03 \mathrm{a}$ & $154.4 \mathrm{a}$ & $13.15 \mathrm{a}$ & $3.75 \mathrm{a}$ & $1.183 \mathrm{a}$ \\
Significance & $1.57 \mathrm{a}$ & $150.0 \mathrm{a}$ & $10.47 \mathrm{a}$ & $3.92 \mathrm{a}$ & $1.279 \mathrm{a}$ \\
\hline & $\mathrm{ns}$ & $\mathrm{ns}$ & $\mathrm{ns}$ & $\mathrm{ns}$ & $\mathrm{ns}$ \\
\hline
\end{tabular}

Means within a column are significantly different according to Tukey's HSD test ( $\mathrm{p} \leq 0.05)$. $*, * *, * * *$ Significant at the $0.05,0.01,0.001$ probability levels, respectively.

ns: Nonsignificant; PP: polypropylene. Characteristics of nonwovens: see Materials and Methods.

similar to that under a PP nonwoven. Row covers modify the microclimate and potentially contribute to a more favorable environment for plant growth, especially when compared to open field (Olle and Bender, 2010). These modifications, however, depend on the physical properties specific to each of the nonwovens, hence each of these covers may affect the microclimate differently, thereby causing some differences in yielding of the radish plants. Biodegradable nonwovens provided slightly higher minimum temperatures than Control PP, but PAR values were lower. We see the causes of a smaller or comparable, but not higher, yield of the plants covered with degradable nonwovens in the lower intensity of PAR under such materials.

The quality structure of the total yield of radish roots was affected by the type of nonwoven in particular seasons and years (Figure 6). In 2012 (Exp. I), the yield quality of radishes covered with SB48/11 was slightly better than that for the control nonwoven. Although there was a similar number of marketable roots, more cracked roots were noted under nonwoven PP. In autumn 2013 (Exp. II) and spring 2014 (Exp. III), cracked roots were a marginal case. In both seasons of experiments mentioned, biodegradable covers caused a decrease in the number of marketable roots. A higher share of small and shapeless roots in the total yield was noted, by $1.4 \%$ and 5.2\% for SB21/13 and SB20/13, respectively, in autumn 2013, and by $12.0 \%, 14.0 \%$, and $19.6 \%$ for SB20/13, SB28/13, and SB21/13, respectively, in spring 2014, in comparison to the nonwoven PP. In autumn 2014 (Exp. III), small and shapeless roots prevailed in yield under every

Figure 6. Quality structure of radish root yield ( $\square$ marketable roots, $\square$ small and shapeless roots, $\square$ cracked roots) as affected by nonwoven type in experiments I-III.

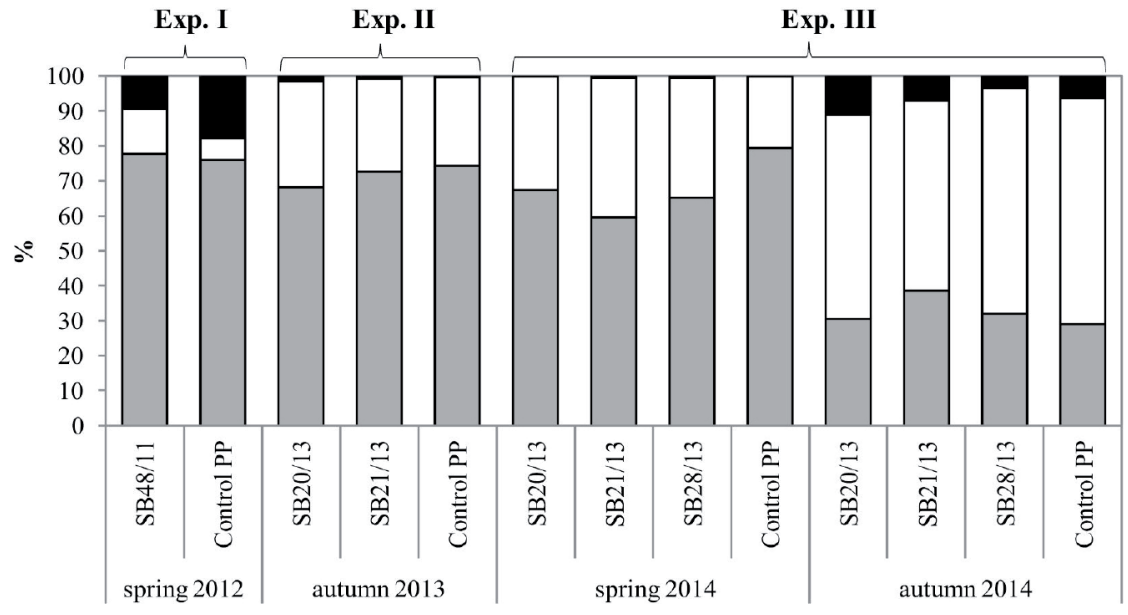


cover, and their smallest share was found for SB21/13, while cracked roots occurred least frequently under SB28/13 in comparison to other covers. The results of this study showed the quite significant, but variable, impact of degradable covers on the yield quality of radishes.

\section{Chemical constituents of radish leaves and roots}

Leaves of radishes covered with SB48/11 had greater dry weight but less soluble sugars than those covered with the commercial PP nonwoven (Table 8; Exp. I). Nonsignificant effect of nonwoven type on the content of chlorophylls and carotenoids in radish leaves was observed.

As noted for leaves, dry weight of radish roots was higher due to covering with SB48/11, and the content of soluble sugars and L-ascorbic acid was higher than in control plants (Table 9; Exp. I). In autumn 2013 (Exp. II) and spring 2014 (Exp. III), L-ascorbic acid content in roots was similar regardless of the cover (Tables 10 and 11). In autumn 2014 (Exp. III), SB20/13 significantly increased the content of this compound in comparison to nonwoven PP. This cover type also increased the soluble sugar content at that time. However, in spring 2014, the soluble sugar content was comparable to that in control plants, but higher than that under other degradable covers. Nonsignificant effect of nonwoven type on dry weight was noted in Exp. III, however, it was lowered by biodegradable covers in the autumn 2013 (Exp. II). In that experiment no effects of covers on soluble sugars in radish roots was noted.

Table 8. Dry weight and soluble sugar, chlorophyll, and carotenoid content in radish leaves as affected by nonwoven type in experiment I. Spring 2012.

\begin{tabular}{|c|c|c|c|c|c|}
\hline Nonwoven type & Dry weight & Soluble sugars & Chlorophyll $a$ & Chlorophyll $b$ & Carotenoids \\
\hline & \multicolumn{2}{|c|}{$\% \mathrm{FW}$} & & $\mathrm{mg} \mathrm{g}^{-1} \mathrm{FW}$ & \\
\hline SB48/11 & $11.79 b$ & $0.40 \mathrm{a}$ & $0.853 \mathrm{a}$ & $0.390 \mathrm{a}$ & $0.136 \mathrm{a}$ \\
\hline Control PP & $11.15 \mathrm{a}$ & $0.60 \mathrm{~b}$ & $0.777 \mathrm{a}$ & $0.355 \mathrm{a}$ & $0.123 \mathrm{a}$ \\
\hline Significance & $* * *$ & $* * *$ & $\mathrm{~ns}$ & ns & ns \\
\hline
\end{tabular}

Means within a column are significantly different according to t-test $(\mathrm{p} \leq 0.05)$.

***Significant at the 0.001 probability level.

ns: Nonsignificant; PP: polypropylene. Characteristics of nonwovens: see Materials and Methods.

Table 9. Dry weight, soluble sugars, and L-ascorbic acid content in radish roots as affected by nonwoven type in experiment I. Spring 2012.

\begin{tabular}{lccc}
\hline Nonwoven type & Dry weight & Soluble sugars & L-Ascorbic acid \\
\cline { 2 - 3 } & \multicolumn{2}{c}{$\% \mathrm{FW}$} & $\mathrm{mg} 100 \mathrm{~g}^{-1} \mathrm{FW}$ \\
SB48/11 & $4.90 \mathrm{~b}$ & $1.73 \mathrm{~b}$ & $29.70 \mathrm{~b}$ \\
Control PP & $4.60 \mathrm{a}$ & $1.59 \mathrm{a}$ & $23.30 \mathrm{a}$ \\
Significance & $*$ & $*$ & $* * *$ \\
\hline
\end{tabular}

Means within a column are significantly different according to t-test $(\mathrm{p} \leq 0.05)$.

$*, * * *$ Significant at the 0.05 and 0.001 probability levels, respectively. ns: Nonsignificant; PP: polypropylene. Characteristics of nonwovens: see Materials and Methods.

Table 10. Dry weight, soluble sugars, and L-ascorbic acid content in radish roots as affected by nonwoven type in experiment II. Autumn 2013.

\begin{tabular}{lccc}
\hline Nonwoven type & Dry weight & Soluble sugars & L-Ascorbic acid \\
\cline { 2 - 3 } & \multicolumn{2}{c}{$\% \mathrm{FW}$} & $\mathrm{mg} 100 \mathrm{~g}^{-1} \mathrm{FW}$ \\
SB20/13 & $4.27 \mathrm{a}$ & $1.27 \mathrm{a}$ & $21.25 \mathrm{a}$ \\
SB21/13 & $4.28 \mathrm{a}$ & $1.23 \mathrm{a}$ & $22.22 \mathrm{a}$ \\
Control PP & $4.38 \mathrm{~b}$ & $1.30 \mathrm{a}$ & $21.74 \mathrm{a}$ \\
Significance & $* *$ & $\mathrm{~ns}$ & $\mathrm{~ns}$ \\
\hline
\end{tabular}

Means within a column are significantly different according to Tukey's HSD test $(\mathrm{p} \leq 0.05)$.

$* *$ Significant at the 0.01 probability level.

ns: Nonsignificant; PP: polypropylene. Characteristics of nonwovens: see Materials and Methods. 
Table 11. Dry weight, soluble sugars, and L-ascorbic acid content in radish roots as affected by nonwoven type in experiment III.

\begin{tabular}{lccc}
\hline Nonwoven type & Dry weight & Soluble sugars & L-Ascorbic acid \\
\cline { 2 - 3 } & \multicolumn{2}{c}{$\% \mathrm{FW}$} & $\mathrm{mg} 100 \mathrm{~g}^{-1} \mathrm{FW}$ \\
Spring 2014 & $3.75 \mathrm{a}$ & $1.66 \mathrm{c}$ & \\
SB20/13 & $3.78 \mathrm{a}$ & $1.52 \mathrm{a}$ & $26.53 \mathrm{a}$ \\
SB21/13 & $3.73 \mathrm{a}$ & $1.60 \mathrm{~b}$ & $27.78 \mathrm{a}$ \\
SB28/13 & $3.78 \mathrm{a}$ & $1.64 \mathrm{bc}$ & $26.39 \mathrm{a}$ \\
Control PP & $\mathrm{ns}$ & $* * * 38 \mathrm{a}$ & $\mathrm{ns}$ \\
Significance & & & \\
Autumn 2014 & $4.35 \mathrm{c}$ & $0.74 \mathrm{~b}$ & $21.45 \mathrm{~b}$ \\
SB20/13 & $3.72 \mathrm{a}$ & $0.59 \mathrm{a}$ & $18.55 \mathrm{a}$ \\
SB21/13 & $3.95 \mathrm{~b}$ & $0.62 \mathrm{a}$ & $17.39 \mathrm{a}$ \\
SB28/13 & $3.74 \mathrm{a}$ & $0.58 \mathrm{a}$ & $18.55 \mathrm{a}$ \\
Control PP & $* * *$ & $* * *$ & $* * *$ \\
Significance & &
\end{tabular}

Means within a column are significantly different according to Tukey's HSD test $(\mathrm{p} \leq 0.05)$.

$* * *$ Significant at the 0.001 probability level.

ns: Nonsignificant; PP: polypropylene. Characteristics of nonwovens: see Materials and Methods.

Covering with nonwoven PP was found to alter the chemical composition of the plants in comparison to an open field (Olle and Bender, 2010). Data describing changes in the content of basic constituents in plants depending on the type of floating nonwoven cover are lacking. Siwek et al. (2012) reported ambiguous effects of biodegradable nonwovens on dry weight and the soluble sugar content of lettuce plants in particular experimental years in comparison to nonwoven PP. Siwek et al. (2013b) compared several degradable nonwovens, and they noted a decrease in soluble sugars and dry weight of onions covered with AAC $50 \mathrm{~g} \mathrm{~m}^{-2}$ as compared to nonwoven PP; plants had a similar content of these compounds. The data obtained by these authors on L-ascorbic acid showed some influence of the type of nonwoven, but do not give grounds for unambiguous interpretation. This shows that the level of these components in plants depends on a specific set of microclimatic conditions under covers and in an open field which differs in individual experimental years.

\section{CONCLUSIONS}

It is worth emphasizing in this study an attempt to introduce various innovative types of nonwoven material, including nonwovens with addition of plant biomass for horticultural production, in this case for radishes. The experiment has shown the possibility of using biodegradable nonwoven materials as floating covers for radish growing in seasons exposed to temperature drops. The comparison of several biodegradable covers compared to a commercial polypropylene nonwoven showed their similar or less favourable effect on radish yield. The latter was probably connected with the limitation of photosynthetically active radiation intensity. The results indicate the necessity of some further refinement of the biopolymers tested, mainly associated with lowering their mass per unit area.

\section{ACKNOWLEDGEMENTS}

This work was supported by the project "Use of biomass in production of environmentally friendly polymer materials" BIOMASA-POIG 01.01.02.-10-123/09-00, PZ 5.1.,co-financed by the EU within the European Regional Development Fund. This work was also supported by the Ministry of Science and Higher Education of the Republic of Poland (statutory activity). 


\section{REFERENCES}

Alwani, M.S., Khalil, H.P.S.A., Asniza, M., Suhaily, S.S., Amiranajwa, A.S.N., and Jawaid, M. 2014. Agricultural biomass raw materials: the current state and future potentialities. p. 77-100. In Hakeem, K.R., Jawaid, M., and Rashid, U. (eds.) Biomass and bioenergy: Processing and properties. Springer, Cham, Switzerland.

Bergeret, A. 2011. Environmental-friendly biodegradable polymers and composites. p. 341-364. In Kumar, S. (ed.) Integrated waste management. Volume I. IntechOpen Limited, London, UK.

Briassoulis, D., Babou, E., Hiskakis, M., and Kyrikou, I. 2015. Analysis of long-term degradation behaviour of polyethylene mulching films with pro-oxidants under real cultivation and soil burial conditions. Environmental Science and Pollution Research 22:2584-2598.

Chen, Y., Tan, L., Chen, L., Yang, Y., and Wang, X. 2008. Study on biodegradable aromatic/aliphatic copolyesters. Brazilian Journal of Chemical Engineering 25(2):321-335.

Ghanbarzadeh, B., and Almasi, H. 2013. Biodegradable polymers. p. 141-185. In Chamy, R., and Rosenkranz, F. (eds.) Biodegradation. Life of science. InTechOpen, Rijeka, Croatia.

Goldwater, A.D., Ekman, J.H., and Rogers, G.S. 2018. The effects of floating row covers on yield and quality of field-grown capsicum (Capsicum annuum L.) Acta Horticulturae 1205:891-896.

Hamasaki, T. 2013. Effect of floating row covers on soil and air temperatures in different seasons. Journal of Agricultural Meteorology 69(2):65-79.

Kalisz, A., Siwek, P., and Sulak, K. 2018. Influence of spunbond degradable floating row covers on microclimate modification and yield of field cucumber. Spanish Journal of Agricultural Research 16(2):e0902.

Kalisz, A., Cebula, S., Siwek, P., Sekara, A., Grabowska, A., and Gil, J. 2014. Effects of row covers using non-woven fleece on the yields, rate of bolting, and quality of heading Chinese cabbage in early spring cultivation. Journal of the Japanese Society for Horticultural Science 83(2):133-141.

Kalisz, A., Siwek, P., and Libik, A. 2017. Evaluation of degradable nonwoven covers on the growth and yield of overwintering leeks. European Journal of Horticultural Science 82(2):98-104.

Kasirajan, S., and Ngouajio, M. 2012. Polyethylene and biodegradable mulches for agricultural applications: a review. Agronomy for Sustainable Development 32(2):501-529.

Kijchavengkul, T., Auras, R., Rubino, M., Ngouajio, N., and Fernandez, R.T. 2008. Assessment of aliphatic-aromatic copolyester biodegradable mulch films. Part I. Field study. Chemosphere 71:942-953.

Krelowska-Kulas, M. 1993. Badanie jakości produktów spożywczych [The study of food quality]. PWN, Warszawa, Poland.

Lichtenthaler, H.K., and Wellburn, A.R. 1983. Determinations of total carotenoids and chlorophylls $a$ and $b$ of leaf extracts in different solvents. Biochemical Society Transactions 603:591-592.

Martín-Closas, L., Costa, J., and Pelacho, A.M. 2017. Agronomic effects of biodegradable films on crop and field environment. p. 35-65. In Malinconico, M. (ed.) Soil degradable bioplastics for a sustainable modern agriculture, green chemistry and sustainable technology. Springer-Verlag, Berlin, Germany.

Ngouajio, M., Auras, R., Fernandez, R.T., Rubino, M., Counts, J.W. Jr., and Kijchavengkul, T. 2008. Field performance of aliphatic-aromatic copolyester biodegradable mulch films in a fresh market tomato production system. HortTechnology 18(4):605-610.

Olle, M., and Bender, I. 2010. The effect of non-woven fleece on the yield and production characteristics of vegetables. Agraarteadus 30(1):24-29.

Ozturk, M.C., Venkataraman, M., and Mishra, R. 2018. Influence of structural parameters on thermal performance of polypropylene nonwovens. Polymers for Advanced Technologies 29(12):3027-3034.

Rekika, D., Stewart, K.A., Boivin, G., and Jenni, S. 2008. Row covers reduce insect populations and damage and improve early season crisphead lettuce production. International Journal of Vegetable Science 15(1):71-82.

Sideman, B. 2017. Row covers. p. 61-79. In Orzolek, M. (ed.) A guide to the manufacture, performance, and potential of plastics in agriculture. Elsevier, Cambridge/Oxford, UK.

Siwek, P., Libik, A., Kalisz, A., and Zawiska, I. 2013a. The effect of biodegradable nonwoven direct covers on yield and quality of winter leek. Folia Horticulturae 25(1):61-65.

Siwek, P., Libik, A., and Zawiska, I. 2012. The effect of biodegradable nonwovens in butterhead lettuce cultivation for early harvest. Folia Horticulturae 24(2):161-166.

Siwek, P., Libik, A., and Zawiska, I. 2013b. The impact of biodegradable nonwoven fabric covers on the yield and quality of overwintering onions. Acta Scientiarum Polonorum, Hortorum Cultus 12(6):3-11.

Twarowska-Schmidt, K., Sulak, K., Galeski, A., Piórkowska, E., Wojtczak, M., and Dutkiewicz, S. 2016. Investigation in melt processing of biodegradable aliphatic-aromatic polyester into fibrous products. Fibres \& Textiles in Eastern Europe 24(6):58-64. 
van Beilen, J.B., and Poirier, Y. 2008. Production of renewable polymers from crop plants. Plant Journal 54:684-701 .

Vroman, I., and Tighzert, L. 2009. Biodegradable polymers. Materials (Basel) 2:307-344.

Waterer, D. 2010. Evaluation of biodegradable mulches for production of warm-season vegetable crops. Canadian Journal of Plant Science 90(5):37-743.

Yemm, E.W., and Willis, A.J. 1954. The estimation of carbohydrates in plant extracts by anthrone. Biochemical Journal 57:508-514.

Zawiska, I., and Siwek, P. 2014. The effect of biodegradable direct covers on the root development, yield and quality of cucumber. Folia Horticulturae 26(1):43-48. 